\title{
循環器疾患の発症率と危険因子 一久山町研究-
}

\section{九州大学医学部 第 2 内科 清 原}

\section{はじめに}

近年，我が国では高齢人口の急速な増加や生活 習慣の欧米化によって，心血管病の疾病構造に変 動がみられ，その病態も変化している可能性があ る。そこで本報告では，当教室が福岡県久山町に おいて長年継続している心血管病の疫学調查の成 績を紹介し, 地域住民における虚血性心臓病 (IHD) および脳卒中の発症率とその危険因子の時代的変 化について述べる。さらに，最近の集团の調查成 績加, 現代の日本人の心血管病とその危険因子 の関係について，インスリン抵抗性の問題を含め て検討する。

久山町研究

本研究は久山町の40歳以上の地域住民を対象と した心血管病の疫学調查である。この町の人口構 成および職業構成は，過去30年間にわたり全国平 均とほぼ一致しており1), 住民は偏りの小さい日本 人の標準的な集団といえる。

1961年の最初の検診受診者から，脳卒中および 心筋梗塞の既発症者を除いて追跡第 1 集団を設定 したが，その後同様に1974年と1988年の検診受診 者からそれぞれ第 2 集団と第 3 集団を創設した. いずれの集団总当該年龄人Пの80\%旦上を含んで おり，地域を代表する集団と考えられる。この3 集団を同じ方法で追跡しているが，いずれも追跡 率は99\%を越えている。転出者を含め全対象者に
ついて，心血管病発症の臨床情報を集めるととも に，死亡例の $80 \%$ 以上を剖検して死因および藏器 病変を調べている。

この3 集団の断面調查および追跡調査の成績を 比較することにより，心血管病の危険因子レベル と, それが心血管病登症に及ぼす影響の時代的変 化を検討することが可能である.

\section{心血管病の危険因子の時代的変化}

過去30年閭に日本人の生活様式は大きく変化し たが，それが心血管病の危険因子にどのような影 響を与之たのであろうか。この問題を明らかにす るために，1961年，1974年，1988年の各集団の追 跡開始時に行った住民検診（40歳以上）から，心 血管病の危険因子の時代的推移を検討した2). 高血 圧（血圧 $\geqq 160 / 95 \mathrm{mmHg}$ ) の頻度は1961年の男性 $27 \%$ ，女性 $24 \%$ か，1988年には男女とも15\%ま で漸減した。この間, 降圧薬常用者は男女とも 1961 年の $2 \%$ から 1988 年の $14 \%$ にまで増加した。久山 町において 1965 年と 1985 年の20年間隔で行った栄 養調査では，成人 1 日当たりの食塩摂取量は1965 年の18g から1985年には11 g に減少した3).つまり， 1960年代から 1980年代にかけて, 降圧薬療法の普 及と食塩摂取量の減少によって高血圧頻度が減少 したことがうかがえる。

一方，肥満 $\left(\mathrm{BMI} \geqq 25.4 \mathrm{~kg} / \mathrm{m}^{2}\right)$ の頻度は，1961 年では男性 $6 \%$ ，女性11\%であったが，時代とと もに増加し，1988年では男女とも20\%になった。

[key words] 虚血性心臓病, 脳梗塞, 前向き追跡研究, 危険因子, 時代的変化 
表 1 循環器疾患発症率の時代的変化

久山町 3 集団の比較, 40 歳以上，追跡各 5 年，性・年齢調整

\begin{tabular}{|c|c|c|c|}
\hline 偱環器疾患 & $\begin{array}{c}\text { 第 | 集団 } \\
(|96| \sim 66 \text { 年 })\end{array}$ & $\begin{array}{c}\text { 第2 } \text { 集団 } \\
(1974 \sim 79 \text { 年) }\end{array}$ & $\begin{array}{l}\text { 第 } 3 \text { 集団 } \\
(1988 \sim 93 \text { 年) }\end{array}$ \\
\hline 脳卒中 & 10.7 & $4.8^{*}$ & $4.6^{*+}$ \\
\hline 脸梗塞 & 7.7 & $3.5^{*}$ & $3.1^{*+}$ \\
\hline 脳出血 & 2.2 & $0.8^{*}$ & $0.8^{*}$ \\
\hline 々モ膜下出血 & 0.8 & 0.5 & 0.7 \\
\hline 虚血性，臟病 & 1.6 & 2.4 & 2.3 \\
\hline
\end{tabular}

死亡率：対 1,000 人年, $* \mathrm{p}<0.05$ vs 第 1 集団, $+\mathrm{p}<0.05$ vs 第 2 集団

これと平行して,高コレステロール血症 $(\geqq 220 \mathrm{mg} /$ $\mathrm{d} l$ )の頻度は1961年の男性 $3 \%$,女性 $7 \%$ から, 1988 年にはそれぞれ $28 \% ， 42 \%$ までに増えた。耐糖能 異常者も時代とともに増加したが，特に1988年に は40～79歳の受診者全員に75 $\mathrm{g}$ 経口糖負荷試験を 行って，耐糖能異常の頻度を検討した。その結果， WHO 基準による糖尿病の有病率は約 $10 \%$ ，IGT (impaired glucose tolerance) は20\%に達してい た'.

1961年の契煙頻度は男性76\%，女性17\%で，男 性の大多数に喫煙習慣が認められた。1988年にな って男性の契煙率はようやく $50 \%$ まで減少し，女 性の契煙者も10\%以下となった。一方，飲酒頻度 はこの30年間に男性は60\%台，女性は $10 \%$ 以下で 推移し，時代的変化はなかった。

\section{心血管病発症率の時代的変化}

3つの集団をそれぞれ 5 年間追跡した成績から， 心血管病発症率の時代的変化を検討した（表 1 ）. 脳卒中発症率 (対 1,000 人年) は第 1 集団の 10.7 力 ら第 2 集団の 4.8 に半減したが，第 3 集団では 4.6 とその減少幅は小さく，ほぼ横這いの状態となっ た。脳卒中を病型別にみると，第 1 集団から第 2 集団にかけて脳梗塞 $(\mathrm{CI})$ は半減し脳出血は $1 / 3$ に減ったが，第 2 集団から第 3 集団にかけてほと んど変化はなかった。一方，心筋梗塞発症と 1 時 間以内の心臟死による突然死を IHD と定義した場 合，その発症率に有意な時代的変化はなかった。 その結果, 第 1 集団では脳卒中の発症率は IHD の 約 7 倍であったが，第 3 集団では 2 倍までその差
が縮まった。

\section{心血管病の危険因子の多変量解析 一第 1 集団亡第 2 集団の比較}

心血管病とその危険因子の関わり合いの時代的 変化を詳しく調べるために，第 1 集団と第 2 集団 をそれぞれ13年間追跡した成績を用いて，心血管 病発症の危険因子の多変量解析を行い，その成績 を両集団で比較した(表 2 )。その結果，IHDに対 して，第 1 集団では年齢，高血圧 $(\geqq 160 / 95 \mathrm{mmHg}$ または高血圧薬服用)，心電図異常(左室肥大ある いは ST 低下), 㓶煙, body mass index が独立し た有意な危険因子となった。一方，第 2 集団では， 心電図異常が有意な危険因子からはずれ，代わり に血清コレステロールが新たな危険因子として登 場した。つまり，高血圧治療が普及し始めた第 2 集団では，高血圧性臓器障害を表す心電図異常の リスクが軽減し，代わりに高脂血症の増加を反映 して血清コレステロールの影響が増大したと考え られる。

CI の危険因子として，第 1 集団では年齢，高血 圧，心電図異常，耐糖能異常，男性が取り上げら れた。これに対し第 2 集団では，年齢と高血圧は 有意な危険因子として残ったが，心電図異常，耐 糖能異常，男性は有意な危険因子とはならなかっ た。すなわち，第 2 集団では，CIに対しても高血 圧治療によって臓器障害の影響が減少しているこ とがうかがえる。一方，近年，増加傾向にある耐 糖能異常がCIの危険因子からはずれたことは一見 奇異に感じられる。この問題をさらに検討した結 
表 2 循環器疾患発症の危険因子の相対危険

多变量解析 ${ }^{*}$, 久山町 2 集団, 追跡各 13 年

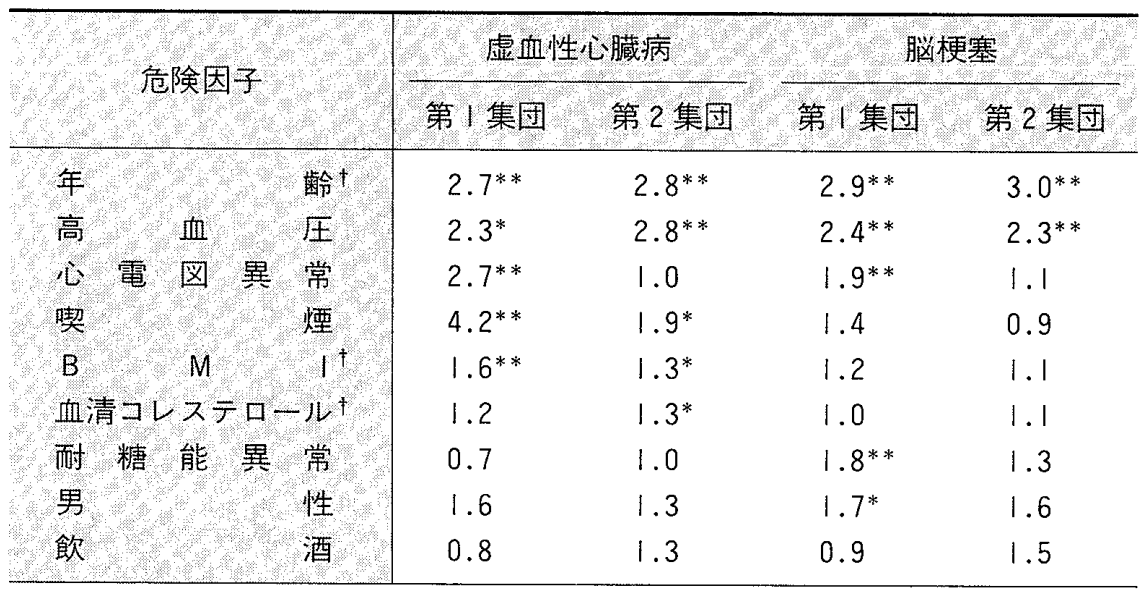

※ Cox 比例ハザードモデル, † 1 標準偏差上昇のリスク, * * p < 0.01, * p < 0.05, $* \mathrm{p}<0.1$

図 1 高血圧レベル別にみた脳梗塞お よび虚血性心疾患発症率

久山町第 3 集団 2,427 名, $40 \sim 79$ 歳, 1988 93年, 性・年齢調整 正常血压：<140/90mmHg, 境界域高血压：140～159／

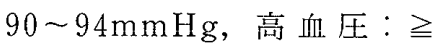
$160 / 95 \mathrm{mmHg}+$ 隆圧薬服用

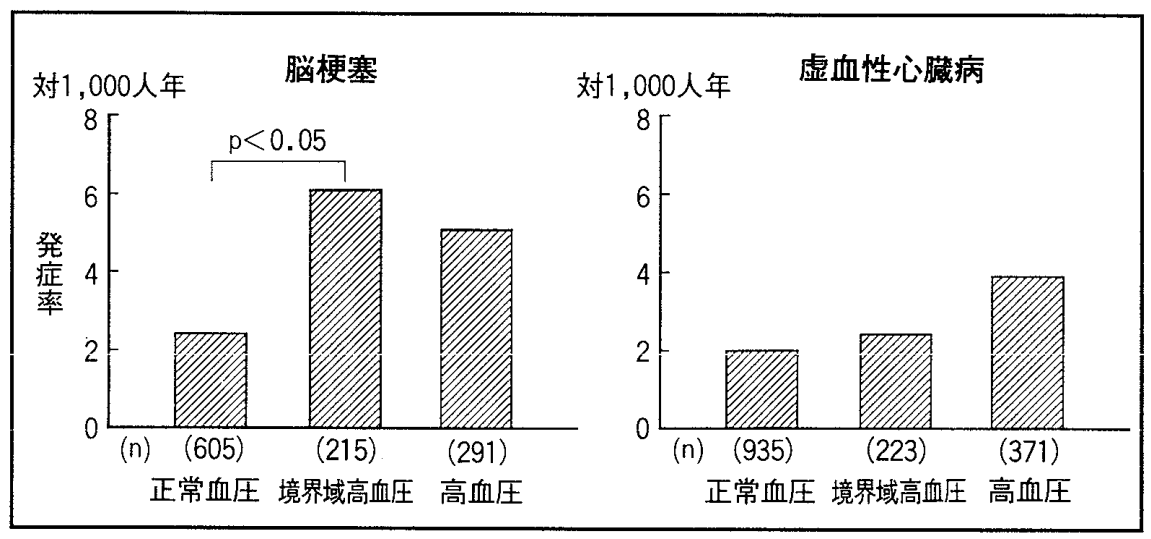

果, 第 1 集団では CI に対する耐糖能異常のリスク は高血圧との相乗効果によって増強されていたが, 第 2 集団では高血圧治療の普及によってこの相乗 効果が消失し，その結果耐糖能異常のリスクも減 少した。つまり，脳梗塞についてみれば，高血圧 管理によって耐糖能異常のリスクも減少すること が示唆される。

\section{最近の集団における心血管病の危険因子}

次に，降圧治療がさらに普及し，代謝異常が大 幅に堌妿し心最近の第 3 集団に䑙いて，心血管病 とその危険因子の関係を検討してみよう。

図 1 は，第 3 集団の追跡開始時の高血圧レベル 別に，その後の 5 年間の CI と IHD の発症率を比 較したものである。境界域高血压群の CI 発症率は 正常血圧群に比べて有意に高かったが, 高血圧群
では発症率の有意な上昇は認めなかった。また， IHD 発症率は高血圧レベルの上昇とともに増加す る傾向にあったが，有意な変化ではなかった。す なわち，高血圧管理が普及した最近の集団では， 心血管病に対する高血圧の影響がさらに小さくな ったことが明らかである。ただし，境界域高血圧 が $\mathrm{CI}$ の危険因子であることは, 今後の高血圧管理 上の重要な問題である.

一方, 第 3 集団のうち糖負荷試験を受けた 40～79 歳の対象者を耐糖能のレベル別に分けて CI および IIDDの発症率をみると, 耐糖能異常のレベルが高 くなるほど CI と IHDの発症率は上昇し, 糖尿病 は両者の有意な危険因子となった（図 2） ${ }^{4}$.

以上の成績から, 最近の日本人では，糖尿病や 脂質代謝異常などの代謝異常が CI およびIHDの 重要な危険因子になったことがうかがえる。この 
図 2 耐糖能レベル別にみた脳梗塞お よび虚血性心疾患発症率

久山町第 3 集団 2,427 名, 40 79 歳, 1988 93年, 性・年路調整 IGT: impaired glucose tolerence

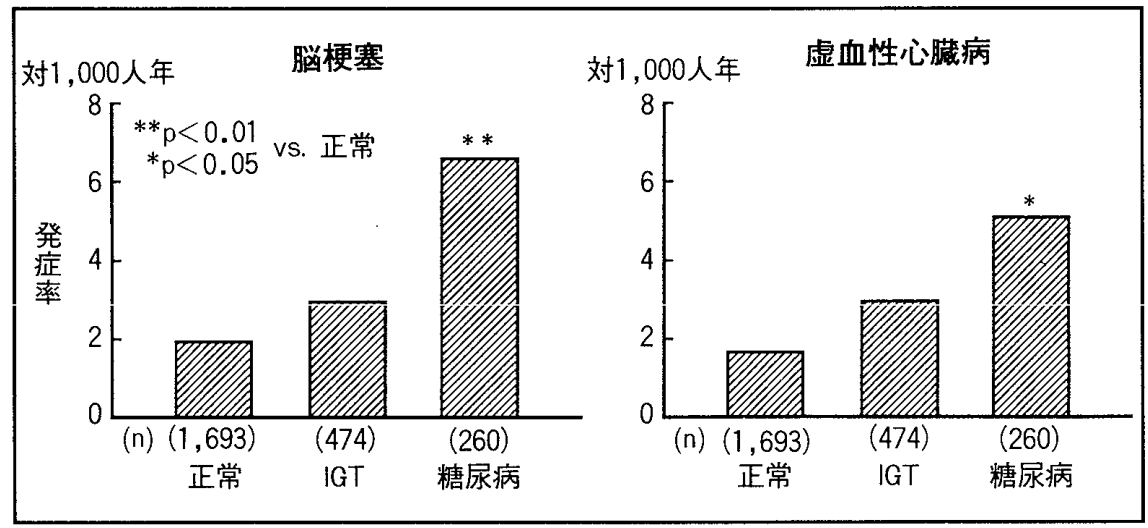

表 3 循環器疾患発症の危険因子の相対危険

ような代謝異常の増加が，近年高血圧管理の普及 や契煙者の減少にもかかわらず, CI 発症率の低下 が鈍化し IHD が減少しない大きな要因と考えられ る。

\section{高齢者の心血管病の危険因子}

我が国では高齢人口が急速に増加しており，高 齢者の心血管病の予防は重要な課題である。そこ で，第 3 集団のうちインスリン治療を受けていな い60歳以上の高齢者 1,097 名（当該年齢人口の 80 \%) を対象に，年齢，性，高インスリン血症（空 腹時インスリン値 $\geqq 11 \mu \mathrm{U} / \mathrm{m} l)$, body mass index, waist/hip ratio, 血清コレステロール, HDL コレ ステロール, 中性脂肪, 空腹時血糖值, 収縮期血 压，心電㘡異常，飲酒，乫煙の13の危険因子を用 いて, IHD およびCI 発症の危険因子の多変量解析 を行った（表 3 $)^{5)}$. その結果, 年齢, 男性, 喫煙 に加えて高インスリン血症がIHD の独立した有意 な危険因子として取り上げられた。一方，CIに対

しては年齢のみが有意な危険因子となった。

高血圧や高脂血症などの古典的な危険因子が心 血管病に与える影響は，高齢になるにつれて減少 するといわれている. 加えて久山町の最近の集団 は，降圧治療の普及によって血圧レベルが低いこ とも，高血圧がIHDの有意な危険因子とならなか った理由の1つにあげられる。逆に，インスリン 抵抗性は加齢とともに増強することから，血清イ ンスリン值が他の危険因子に比べて相対的に IHD の強いリスクになったと考えられる。

一方，血清インスリン值と CI 発症の間には明ら
多変量解析，久山町1,097名，60歳以上，1988～93年

\begin{tabular}{|c|c|c|}
\hline 危険因子 & 虚血性心臟病 & 脳梗塞 \\
\hline 年 齢a & $2.0^{* *}$ & $1.9 * *$ \\
\hline 男 性 & $2.7^{*}$ & \\
\hline 照 喓 & $2.5^{*}$ & \\
\hline 言インスリン血症 & $3.8^{* *}$ & \\
\hline
\end{tabular}

a) 1 標準偏差上昇のリスク，** $\mathrm{p}<0.01 ， * \mathrm{p}<0.05$ その他の検討因子：BMI, 腹团/腰团比, 血清コレステロ 一ル, HDL-コレステロール, 中性脂肪, 空腹時血糖値, 収縮期血圧，心電図異常，飲酒

かな関係は認めなかった。この成績の違いは，動 脈の大きさや部位によって，高インスリン血症あ るいはインスリン抵抗性に対する感受性が違うこ とに起因すると思われる，インスリン抵抗性は脳 動脈のなかでも比較的太い血管の動脈硬化と強く 関連することが報告されている77. 従来より，日本 人は細動脈硬化に基づくラクナ梗塞が多いことが 特徵とされているが，久山町の最近の集団でもこ の特徵に変わりない。したがって，日本人では， 高インスリン血症と CIの間に有意な関係を見いだ しにくいことが示唆される。

\section{おわりに}

我が国では，1970年代から80年代にかけて高血 圧管理が普及し，脳卒中の死亡率，発症率は大幅 に減少した。しかし，近年日本人の生活様式が欧 米化して肥満, 高脂血症, 糖尿病などの代謝異常 者が増えこれらが脳卒中およびIHDの危険因子 として台頭している。したがって，心血管病を今 
後さらに減少させるには，最大の危険因子である 高血圧の予防・治療・管理をひき続き徹底させる とともに，代謝異常など高血圧以外の危険因子を 早期に発見し，その予防対策を講じることが重要 となった.一方, 高齢者の IHD を予防するうえで,

高インスリン血症，あるいはそれに反映されたイ ンスリン抵抗性の是正が重要と考えられる。しか し，高齢者の脳卒中に対する尒防手段は必ずしも 明らかにされて扮らず，今後解決すべき大きな課 題といえよう。

献

4) Fujishima M. et al. : Diabetes and cardiovascular disease in a prospective population survey in Japan: The Hisayama Study. Diabetes 1996 ; 45(suppl 3) : S14-S16

5）清原 裕 他：心血管病危険因子としてのインスリ ン抵抗性. 日老医誌 $1997 ； 34$ (in press)

6) Fink R. I. et al. : Mechanisms of insulin resistance in aging. $\mathrm{J}$ Clin Invest $1983 ; 71: 1523^{-}$ 1535

7) Shinozaki K. et al. : Role of insulin resistance associated with compensatory hyperinsulinemia in ischemic stroke. Stroke $1996 ; 27$ : $37-43$ 